\title{
The role of thermodynamics in biochemical engineering
}

\author{
Urs von Stockar
}

Keywords. Biocalorimetry, biocatalysis, biomolecules, biothermodynamics, Gibbs energy dissipation, systems biology.

\begin{abstract}
This article is an adapted version of the introductory chapter of a book whose publication is imminent. It bears the title "Biothermodynamics The role of thermodynamics in biochemical engineering." The aim of the paper is to give a very short overview of the state of biothermodynamics in an engineering context as reflected in this book. Seen from this perspective, biothermodynamics may be subdivided according to the scale used to formalize the description of the biological system into three large areas: (i) biomolecular thermodynamics (most fundamental scale), (ii) thermodynamics of metabolism (intermediary scale), and (iii) whole-cell thermodynamics ("black-box" description of living entities). In each of these subareas, the main available theoretical approaches and the current and the potential applications are discussed. Biomolecular thermodynamics (i) is especially well developed and is obviously highly pertinent for the development of downstream processing. Its use ought to be encouraged as much as possible. The subarea of thermodynamics of live cells (iii), although scarcely applied in practice, is also expected to enhance bioprocess research and development, particularly in predicting culture performances, for understanding the driving forces for cellular growth, and in developing, monitoring, and controlling cellular cultures. Finally, there is no question that thermodynamic analysis of cellular metabolism (ii) is a promising tool for systems biology and for many other applications, but quite a large research effort is still needed before it may be put to practical use.
\end{abstract}




\section{Introduction}

Thermodynamics has had an enormous impact on a very wide variety of fields, including chemistry, biology, physics, geology, and in particular on applied engineering sciences such as chemical engineering [1]. Systematic application of chemical thermodynamics to process technology is one of the reasons why petrochemical plants can often be designed and petrochemical processes be developed with a bare minimum, if any, of experimental work.

In biochemical engineering, the situation is radically different. The need for experimental trials is so overwhelming in bioprocess development that more often than not, extensive use is made of massively parallel experimentation involving such tools as microtiter plates, minireactors, robotic set-ups, and statistical experimental design. Therefore, the development of high-throughput systems and analytical equipment is now pursued at a very high pace. It can be speculated, however, that rigorous application of thermodynamics in biochemical engineering may be able to rationalize greatly bioprocess development and obviate a substantial fraction of this need for tedious experimental work [2].

It was this vision that motivated a number of scientists about twenty years ago to organize an advanced course in thermodynamics for biochemical engineers to stimulate them to use thermodynamics more systematically in their work, and also to encourage further research in this area [2]. In the last 20 years this course has been taught seven times at various European locations. A substantial amount of course material, accumulated over the years, is now made available to a wider readership in an updated form in the form of a book [3]. Written by authorities in the field, who are listed in Table 1, it covers most aspects relevant for biochemical engineering and contains chapters written as introductions for newcomers in the field of biothermodynamics as well as reviews of the latest cutting-edge research.

Here we reproduce an adapted form of the introductory chapter of this new book. The aim is to give the reader a short overview of the state of biothermodynamics in an engineering context as reflected in this book.

Seen from the perspective of biochemical engineering, biothermodynamics may be subdivided into three large areas according to the scale used to formalize description of the biological system [4] (Figure 1). The most fundamental level uses a system description at a truly molecular level and could be termed biomolecular thermodynamics. It appears at the bottom of Figure 1 and is by far the best developed of the three areas. Biomolecular thermodynamics may be applied to analyze a large number of technically 


\begin{tabular}{|c|c|c|}
\hline Author & Affiliation & $\begin{array}{l}\text { Contribution } \\
\text { to chapters }\end{array}$ \\
\hline John F. Carpenter & $\begin{array}{l}\text { University of Colorado, } \\
\text { Boulder, USA }\end{array}$ & 14 \\
\hline Eva Y. Chi & $\begin{array}{l}\text { University of New Mexico, } \\
\text { Albuquerque, USA }\end{array}$ & 14 \\
\hline A. Espah Borujeni & $\begin{array}{l}\text { Delft University of } \\
\text { Technology, The Netherlands }\end{array}$ & 21 \\
\hline Michael T. Gude & $\begin{array}{l}\text { Delft University of } \\
\text { Technology, The Netherlands }\end{array}$ & 9 \\
\hline Charles A. Haynes & $\begin{array}{l}\text { University of British } \\
\text { Columbia, Vancouver, BC, } \\
\text { Canada }\end{array}$ & $5,8,15$ \\
\hline J. J. Heijnen & $\begin{array}{l}\text { Delft University of } \\
\text { Technology, The Netherlands }\end{array}$ & 18,21 \\
\hline Curtis B. Hughesman & $\begin{array}{l}\text { University of British } \\
\text { Columbia, Vancouver, BC, } \\
\text { Canada }\end{array}$ & 15 \\
\hline E. Jamalzadeh & $\begin{array}{l}\text { Delft University of } \\
\text { Technology, The Netherlands }\end{array}$ & 21 \\
\hline Marcel L. Jansen & $\begin{array}{l}\text { Delft University of } \\
\text { Technology, The Netherlands }\end{array}$ & 11 \\
\hline Hans-Olof Johansson & $\begin{array}{l}\text { University of British } \\
\text { Columbia, Vancouver, BC, } \\
\text { Canada }\end{array}$ & 8 \\
\hline Gunnar Karlström & University of Lund, Sweden & 8 \\
\hline Jürgen U. Keller & $\begin{array}{l}\text { University of Siegen, } \\
\text { Germany }\end{array}$ & 20 \\
\hline Y. S. Kim & $\begin{array}{l}\text { University of California, } \\
\text { Berkeley, USA }\end{array}$ & 6 \\
\hline Karel Ch. A. M. Luyben & $\begin{array}{l}\text { Delft University of } \\
\text { Technology, The Netherlands }\end{array}$ & 11 \\
\hline Thomas Maskow & $\begin{array}{l}\text { Helmholtz Center of } \\
\text { Environmental Research, } \\
\text { Leipzig (UFZ), Germany }\end{array}$ & $5,17,22$ \\
\hline Willem Norde & $\begin{array}{l}\text { Wageningen University } \\
\text { (WUR), The Netherlands }\end{array}$ & $4,7,12$ \\
\hline
\end{tabular}




\begin{tabular}{|c|c|c|}
\hline Author & Affiliation & $\begin{array}{l}\text { Contribution } \\
\text { to chapters }\end{array}$ \\
\hline John M. Prausnitz & $\begin{array}{l}\text { University of California, } \\
\text { Berkeley, USA }\end{array}$ & $2,3,6,10$ \\
\hline Theodore W. Randolph & $\begin{array}{l}\text { University of Colorado, } \\
\text { Boulder, USA }\end{array}$ & 14 \\
\hline E. S. J. Rudolph & $\begin{array}{l}\text { Delft University of } \\
\text { Technology, The Netherlands }\end{array}$ & 9 \\
\hline Adrie J. J. Straathof & $\begin{array}{l}\text { Delft University of } \\
\text { Technology, The Netherlands }\end{array}$ & 13 \\
\hline H. Taymaz-Nikerel & $\begin{array}{l}\text { Delft University of } \\
\text { Technology, The Netherlands }\end{array}$ & 21 \\
\hline Folke Tjerneld & University of Lund, Sweden & 8 \\
\hline Robin F. B. Turner & $\begin{array}{l}\text { University of British } \\
\text { Columbia, Vancouver, BC, } \\
\text { Canada }\end{array}$ & 15 \\
\hline Luuk A. M. van der Wielen & $\begin{array}{l}\text { Delft University of } \\
\text { Technology, The Netherlands }\end{array}$ & 9,11 \\
\hline Walter M. van Gulik & $\begin{array}{l}\text { Delft University of } \\
\text { Technology, The Netherlands }\end{array}$ & 21 \\
\hline P. J. T. Verheijen & $\begin{array}{l}\text { Delft University of } \\
\text { Technology, The Netherlands }\end{array}$ & 21 \\
\hline Patricia V. Vazquez Villegas & $\begin{array}{l}\text { University of British } \\
\text { Columbia, Vancouver, BC, } \\
\text { Canada }\end{array}$ & 8 \\
\hline Vojislav Vojinovic & $\begin{array}{l}\text { Nestlé Product Technology } \\
\text { Center, Konolfingen, } \\
\text { Switzerland }\end{array}$ & 22 \\
\hline Urs von Stockar & $\begin{array}{l}\text { Swiss Federal Institute of } \\
\text { Technology Lausanne } \\
\text { (EPFL), Switzerland }\end{array}$ & $1,16,19,22$ \\
\hline
\end{tabular}

Table 1. List of authors of the book Biothermodynamics. 


\section{Live Cultures}

\section{Whole-cell thermodynamics}

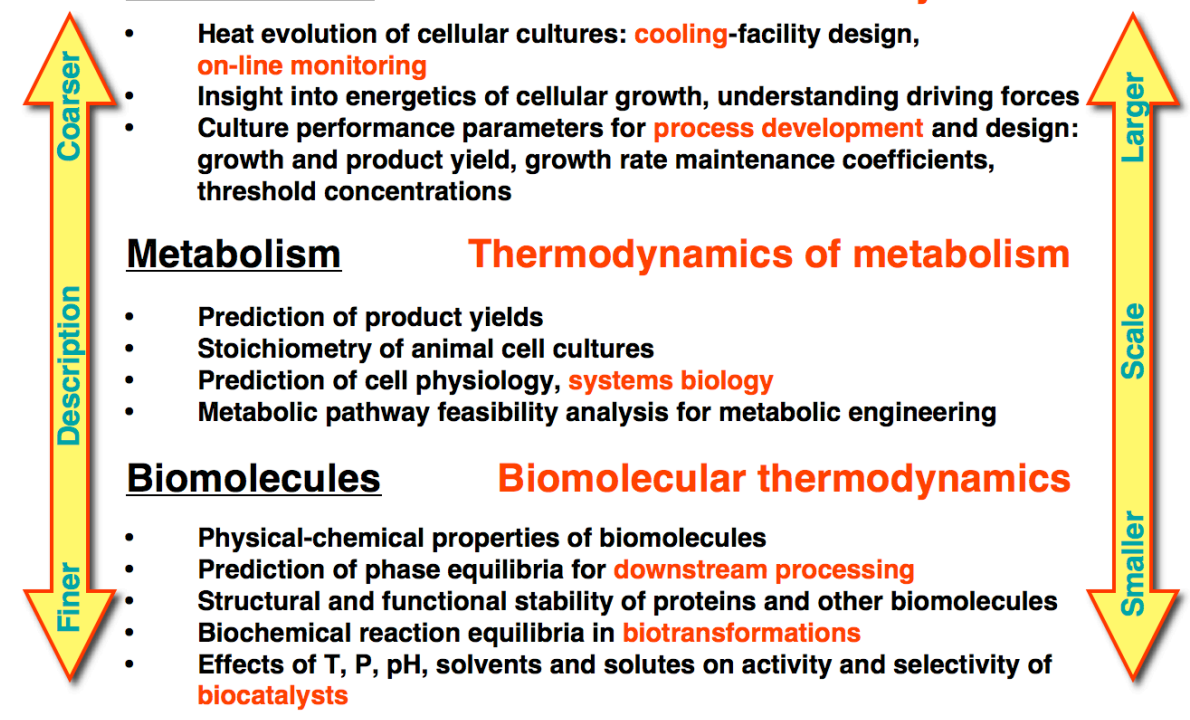

Figure 1. Subdividing biothermodynamics into three areas according to the scale at which the biological system is described. In red: important areas of application.

highly relevant areas and processes, including separation processes such as L/L extraction, chromatography, salting out, partitioning of proteins using aqueous two-phase systems (ATPS), and more (cf. Figure 1). Thermodynamics at the biomolecular level may also be used to understand and to optimize the stability and activity of proteins and other biomolecules, thus leading to such applications as biocatalysis in conventional and nonconventional media, inclusion-body reprocessing, and protein engineering.

The application of molecular thermodynamics to living cells is much more difficult. Attempts to develop such applications have yielded thermodynamic analyses of metabolism aiming at the intermediary level of metabolic pathways (Figure 1). This type of thermodynamics has mainly been used in the context of systems biology and has met with moderate success. It refers to the least well-developed area of the three appearing in Figure 1.

Thermodynamic analysis of live systems is however possible by radically simplifying the description and by modeling the cells as black-box identities. This leads to the coarsest system description and could be called "Whole-cell thermodynamics" (top of Figure 1). Although not yet systematically applied in practice, research results suggest that this form of 
biothermodynamics is useful for understanding the driving forces for cellular growth, for developing, monitoring, and controlling cellular cultures, and for predicting cellular culture parameters such as yields, growth rates, and maintenance requirements [4]. It seems likely that this form of biothermodynamics will also play a role in synthetic biology by enabling an assessment of the stoichiometric and kinetic potential of hypothetical strains with modified genomes engineered to fulfill a defined metabolic task.

\section{Fundamental concepts in equilibrium thermodynamics}

The organization of the new book is shown schematically in Table 2; it differs from the structure proposed in Figure 1 for pedagogical reasons. Instead of subdividing the subject into the three large areas proposed in Figure 1, the chapters were arranged according to the molecular assemblies as described by the respective branches of thermodynamics. This creates a structure that follows more or less the various applications of biothermodynamics.

The chapters of the first section recall the most important fundamentals of thermodynamics. They were not intended to provide a full-fledged introduction to thermodynamic fundamentals, but merely serve as short reminders for the reader.

Chapter 2 surveys the fundamentals of molecular phase equilibrium thermodynamics. Special chapters are included to describe those aspects of thermodynamics that are of particular importance to biochemistry: most biomolecules carry electrostatic charges (Chapter 5), leading to osmotic virial models for predicting the equilibria of proteins between aqueous solutions and other phases (Chapter 3). Particular emphasis is placed on the physical chemistry of water, the all-important solvent for the overwhelming majority of life processes (Chapter 4). Further fundamental particularities of biological systems are self-assembling entities in water such as micelles and membranes. In view of their fundamental importance for the existence, structure, and functions of living organisms, we devote a separate chapter to this topic (Chapter 7, placed in Section II). 


\section{Chapters}

Potential applications

\begin{tabular}{|c|c|c|}
\hline I & Fundamentals & \\
\hline 1 & $\begin{array}{l}\text { The role of thermodynamics in biochemical } \\
\text { engineering (von Stockar) }\end{array}$ & \multirow{5}{*}{$\begin{array}{l}\text { General overview } \\
\text { General insight into equi- } \\
\text { libria }\end{array}$} \\
\hline 2 & $\begin{array}{l}\text { Phase equilibria in non-electrolyte systems } \\
\text { (Prausnitz) }\end{array}$ & \\
\hline 3 & $\begin{array}{l}\text { Virial expansion for chemical potentials for } \\
\text { L-L equilibria (Prausnitz) }\end{array}$ & \\
\hline 4 & Water (Norde) & \\
\hline 5 & $\begin{array}{l}\text { The thermodynamics of electrically charged } \\
\text { molecules in solution (Maskow, Haynes) }\end{array}$ & \\
\hline II & Charged species, gels, and other soft systems & \multirow{7}{*}{$\begin{array}{l}\text { Solution behavior of } \\
\text { polymers } \\
\text { Salting out, precipitation } \\
\text { extraction, chromatogra- } \\
\text { phy, resin swelling, phas } \\
\text { splitting, general rele- } \\
\text { vance for down-stream } \\
\text { processing }\end{array}$} \\
\hline 6 & $\begin{array}{l}\text { Polymers, polyelectrolytes and gels (Kim, } \\
\text { Prausnitz) }\end{array}$ & \\
\hline 7 & $\begin{array}{l}\text { Self-assembly of ampiphilic molecules } \\
\text { (Norde) }\end{array}$ & \\
\hline 8 & $\begin{array}{l}\text { Molecular thermodynamics of partition- } \\
\text { ing in aqueous two phase systems (Johans- } \\
\text { son, Vazquez Villegas, Karlström, Tjerneld, } \\
\text { Haynes) }\end{array}$ & \\
\hline 9 & $\begin{array}{l}\text { Generalization of thermodynamic properties } \\
\text { for selection of bioseparation processes (van } \\
\text { der Wielen, Rudolph, Gude) }\end{array}$ & \\
\hline 10 & $\begin{array}{l}\text { Protein precipitation with salts and/or poly- } \\
\text { mers (Prausnitz) }\end{array}$ & \\
\hline 11 & $\begin{array}{l}\text { Multicomponent ion exchange equilibria } \\
\text { of weak electrolyte biomolecules (van der } \\
\text { Wielen, Jansen, Luyben) }\end{array}$ & \\
\hline III & Stability and activity of biomacromolecules & \multirow{5}{*}{$\begin{array}{l}\text { Biocatalysis in general } \\
\text { and in non-conventional } \\
\text { media, biocatalyst engi- } \\
\text { neering, protein engineer- } \\
\text { ing, DSP, inclusion-body } \\
\text { reprocessing, shelf life of } \\
\text { biomolecules and of their } \\
\text { solutions }\end{array}$} \\
\hline 12 & Proteins (Norde) & \\
\hline 13 & $\begin{array}{l}\text { Thermodynamics in multiphase biocatalysis } \\
\text { (Straathof) }\end{array}$ & \\
\hline 14 & $\begin{array}{l}\text { Physical stability of protein solutions (Chi, } \\
\text { Carpenter, Randolph) }\end{array}$ & \\
\hline 15 & $\begin{array}{l}\text { Stability of DNA (Hughesman, Turner, } \\
\text { Haynes) }\end{array}$ & \\
\hline
\end{tabular}




\section{Chapters}

Potential applications

\begin{tabular}{|c|c|c|}
\hline & & \\
\hline 16 & $\begin{array}{l}\text { Live Cells as Open Non-Equilibrium Sys- } \\
\text { tems (von Stockar) }\end{array}$ & \multirow{5}{*}{$\begin{array}{l}\text { Insight, heat removal, } \\
\text { monitoring of biopro- } \\
\text { cesses, coupled fluxes in } \\
\text { cellular processes, pre- } \\
\text { diction of biomass and } \\
\text { product yields, prediction } \\
\text { of culture performance } \\
\text { parameters }\end{array}$} \\
\hline 17 & Chip Biocalorimetry (Maskow) & \\
\hline 18 & $\begin{array}{l}\text { Thermodynamics to Predict Parameters for } \\
\text { Microbial Growth (Heijnen) }\end{array}$ & \\
\hline 19 & $\begin{array}{l}\text { Biothermodynamics for Live Cells (von } \\
\text { Stockar) }\end{array}$ & \\
\hline 20 & $\begin{array}{l}\text { Thermodynamic Analysis of Photosynthesis } \\
\text { (Keller) }\end{array}$ & \\
\hline $\mathrm{V}$ & Thermodynamics of metabolism & \\
\hline 21 & $\begin{array}{l}\text { Thermodynamics of Dicarboxylic Acid } \\
\text { Production in Microorganisms (Taymaz- } \\
\text { Nikerel, Jamalzadeh, Espah Borujeni, } \\
\text { Verheijen, van Gulik, Heijnen) }\end{array}$ & \multirow[t]{2}{*}{$\begin{array}{l}\text { Systems biology, } \\
\text { metabolic engineering, } \\
\text { synthetic biology }\end{array}$} \\
\hline 22 & $\begin{array}{l}\text { Thermodynamic analysis of metabolic path- } \\
\text { ways (von Stockar, Maskow, Vojinovic) }\end{array}$ & \\
\hline
\end{tabular}

Table 2. Structure of the book Biothermodynamics.

\section{Charged species, gels, and other soft systems}

Sections II and III (Table 2) are devoted to the most fundamental area termed "Biomolecular thermodynamics" in Figure 1. By focusing on only a few selected examples, they illustrate the wide range of applications for which thermodynamic analysis may be utilized: Aqueous two-phase systems (ATPS) (Chapter 8), biomolecule separation by liquid-liquid extraction using mixed solvents (Chapter 9), protein separation by salting out (Chapter 10) or by ion exchange chromatography (Chapter 11), and the use of hydrogels and their swelling behavior for many applications including drug delivery, drug formulation, applications in food and feed, consumer products, technical foams, superabsorbent materials, and many more (Chapter 6).

It has been recognized for a long time that it is difficult to use classical models for excess Gibbs energies such as UNIFAC to predict the partition behavior of charged biomolecules [2,5]. Biomolecules often are polymers and most bear $\mathrm{pH}$-dependent charges. This is one of the reasons why the 


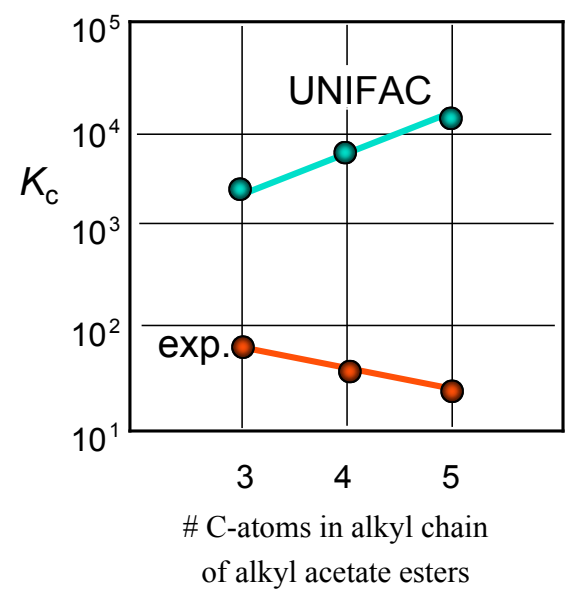

Figure 2. Experimental partition coefficients of Pen G (K PenG) from water to alkyl acetate esters [6] and those predicted using UNIFAC (reproduced from Ref. [2]).

successful predictive models available for non-charged, small molecules cannot be used straightforwardly in biochemical engineering. A characteristic example is the description of the phase behavior of Penicillin $\mathrm{G}$ in water-alkyl acetate esters, which are typical industrial solvent-extraction systems. Although Penicillin G is one of the smaller biomolecules of industrial relevance, it is large when compared to most petrochemicals. Its industrial importance is highlighted by the considerable scale of operation (estimated in hundreds of tons/year) and by its 60-year history. Using one of the more powerful predictive models (UNIFAC), partition coefficients between an organic and an aqueous phase were overestimated by several orders of magnitude. Even worse, tendencies for homologous series of solvents were incorrectly predicted, as shown in Figure 2.

This implies that design and optimization for these and even more complex processes have to follow the laborious and costly empirical route, rather than use of computer-aided flow sheeting programs for the evaluation of alternatives. This is an area where molecular thermodynamics can make a useful contribution $[5,7]$.

The chapters included in Section II reflect three main research trends that have been pursued during the last 20 years to improve models for successful correlations: (i) the extension of existing excess models (NRTL, UNIQUAC, etc., see, e.g., [8]), (ii) osmotic virial models, and, closely related, models based on considering attractive and repulsive interactions 
between solutes via potentials of mean force (see, e.g., [9]), and (iii) correlative methods $[10,11]$. For instance, swelling behavior of charged and uncharged gels can be described with a combination of the Flory-Huggins theory, elastic deformation, and electrostatic effects (Chapter 6). Chapter 8 demonstrates how the partition behavior and the driving forces for partitioning may quantitatively be understood and modeled using methods based on the Flory-Huggins theory. Chapter 9 illustrates the usefulness of correlations based on a correctly formulated thermodynamic approach.

\section{Stability and activity of biomacromolecules}

Another major area where thermodynamics may have an impact concerns the structural and functional stability as well as the activity of proteins and other biomacromolecules. Engineers have to make sure that structure and function are maintained in the native state during both production and isolation of the biomarcromolecule. In addition, they have to guarantee an appropriate shelf life if the bioproduct is to make its way into the market. For reprocessing inclusion-bodies by unfolding and refolding, understanding the thermodynamics of these processes is of major importance.

Chapter 12 provides a general introduction into the structure and the structural stability of proteins, whereas Chapter 14 represents a more specialized review of the stability of protein solutions. It emphasizes particularly the thermodynamics of denaturation by aggregation, and thus goes beyond the better-known mechanisms of destabilization by chaotropic agents and by rising (or decreasing) temperatures.

Ten years ago, von Stockar and van der Wielen [2] noted a scarcity of literature on the thermodynamics of biopolymers other than proteins. They pointed out that this area might become important for such applications as somatic gene therapy, DNA immunization and vaccination, and transient expression of gene products for rapid production of preparative amounts of recombinant proteins. We thus include a cutting-edge research review on DNA stability in Chapter 15.

Thermodynamics may also become an important tool for understanding and manipulating not only stability, but also the function of biopolymers such as proteins. Chapter 13 contains a didactic introduction into the thermodynamics of aqueous enzyme-catalyzed reactions. It was recognized a long time ago [12] that using multiphase reaction mixtures in biocatalysis enabled engineers to manipulate the thermodynamics of the transformations by shifting equilibrium yields, suppressing undesired side and hy- 
drolysis reactions, improving final product concentrations, and facilitating downstream processing. Chapter 13 places its main focus on biocatalysis in non-conventional media and provides a basis for rational "phase and reaction equilibrium engineering" in biocatalysis.

\section{Thermodynamics of live cells}

A majority of activities in biochemical engineering concerns living systems such as cultures of microbial, animal and plant cells, or whole organisms such as plants and animals. Since bioprocess development of living cell cultures requires disproportionate amounts of experimental trials, application of thermodynamic analysis for reducing this need appears particularly desirable. Rigorous application of thermodynamics to live systems such as cellular cultures pose, however, a daunting task in view of the large complexity of reaction mixtures, giant biological molecules, a vast variety of intra- and intermolecular attraction and repulsion forces, multiple driving forces, compartmentalization and multiphase systems, and a multitude of biological, chemical, and physical processes that occur in the interior of a cell.

These are some of the reasons why the thermodynamic description of living cells is normally simplified radically by treating cells as black boxes or chemical entities, resulting in the subarea of the scale in Figure 1 on the opposite end from biomolecules. The chapters in Sections IV and V concern this form of thermodynamics as well as the attempt to refine the description toward the biomolecular scale by opening the black box and introducing a thermodynamic analysis at the intermediary scale of metabolism.

Living cells, just like technical process equipment in action, represent open systems operating far from equilibrium, which are prerequisites for fulfilling any useful function. Chapter 16 recalls briefly the principles of energy and entropy balances for open systems and provides an introduction to the basics of non-equilibrium thermodynamics.

Because they are open non-equilibrium systems, virtually all living beings constantly dissipate heat (endothermic life forms are exceedingly rare, but their existence has been calorimetrically demonstrated by Ref. [13]). This dissipation is exploited analytically in biocalorimetry; a novel example is described in Chapter 17. Heat release by cellular cultures also has some technical relevance in that this heat must be removed from the bioreactor by cooling, a major technical challenge at large scale. On the other hand, the biological heat dissipation also offers the opportunity for easy 
culture monitoring and on-line process control at large scale. In such applications, the heat signal is linked to and interpreted in terms of biological activity by applying the First Law in the framework of a black-box model as described in the first part of Chapter 19.

The deeper reason for continuous heat dissipation of living beings is their need constantly to dissipate, i.e., to destroy Gibbs energy. According to non-equilibrium thermodynamics (NET), and assuming that there is growth, the rate of Gibbs energy dissipation in Watt per unit biomass is given by the product $\mu \cdot \Delta_{\mathrm{r}} G$, where $\mu$ represents the specific growth rate, or "flux" in NET jargon, and $\Delta_{\mathrm{r}} G$ the Gibbs energy change of the growth reaction. In NET parlance the latter represents the "force," i.e., the driving force for growth. For $\mu$ to be positive, $\Delta_{\mathrm{r}} G$ must be negative.

Important parts of Chapters 18 and 19 summarize what we know about the Gibbs energy of reaction $\left(\Delta_{\mathrm{r}} G\right)$ for cellular growth. It cannot be measured in a calorimeter like $\Delta_{\mathrm{r}} H$, but $\Delta_{\mathrm{r}} G^{0}$ may be calculated if the stoichiometry of the black-box growth process is known. On the other hand, this stoichiometry, and with it the all-important biomass yield $Y_{\mathrm{X} / \mathrm{S}}$, may be predicted if $\Delta_{\mathrm{r}} G$ for the growth process is known. By evaluating $\Delta_{\mathrm{r}} G^{0}$ from measured growth stoichiometries and biomass yields for hundreds of different microbial growth experiments, and by correlating the values to simple molecular properties of the carbon- and energy substrates, it has been possible in the last 20 years to propose methods for the rough prediction of the all-important parameter $Y_{\mathrm{X} / \mathrm{S}}$ from an absolute minimum of prior information $[14,15]$. Similar methods have been published for predicting other important culture-performance parameters such as maintenance requirements, maximum growth rates, product yields, and the like [16]. Chapter 18 explains the use of these concepts for solving practical problems. Whole-cell thermodynamics is useful not only for understanding the driving forces for growth in microbial cultures, but also for roughly predicting the optimal culture performance of given strains and for comparing different microbial systems before any culture trials have been carried out.

The prediction of fermentation-product yields might become more important in the future due to the global tendency to replace, given time, the current fossil-based economy by one that is more bio-based. Instead of extraction from oil-based resources, organic raw materials will thus increasingly be produced sustainably by photosynthetic growth, and will then be transformed into biofuels and building blocks for the chemical industry using biorefineries mainly based on anaerobic fermentations. A particular thermodynamic analysis of photosynthesis is outlined in Chapter 20, and various process variants may be compared in planning biorefineries by us- 
ing predictions of growth and product yields as described in Chapters 18 and 19.

\section{Thermodynamic analysis of metabolism}

Can thermodynamics offer the potential to predict the performance of hypothetical new strains that would be specifically engineered for producing a given desired bioproduct at large scale? Chapter 21 demonstrates this approach using the examples of succinic and fumaric acids that represent particularly interesting building blocks for a bio-based polymer industry. It follows from this chapter that, while whole-cell thermodynamics provides initial guidance for such an endeavor, the assessment of the feasibility of constructing a functional strain producing the desired product requires a much more detailed analysis, allowing for existing genes and enzymes, export systems, the effect of culture $\mathrm{pH}$, and so on.

These studies thus also show the limitations of thermodynamic blackbox analysis. Whole-cell thermodynamics cannot predict complex stoichiometries such as those featured by animal or plant cells; it cannot predict yields for products unrelated to catabolism, or assess the feasibility of genetically engineered cells or strains fitted with complex heterologous pathways. For such tasks, there is a need for opening the black box and for analyzing the thermodynamics of living cells, if not at the molecular, then at least at the intermediate level of the metabolic pathways as shown in Figure 1.

Thermodynamic analysis of metabolism has been attempted in the context of systems biology. This discipline tries to use genomic data to reconstruct the fluxes quantitatively through the whole metabolism on a genomewide scale by applying mathematical techniques such as metabolic flux or metabolic balance analysis. Due to the large number of open reading frames and their genetic products (e.g., enzymes) as compared to the available balance equations, the result is usually not a single solution but a solution space. In this situation, it was expected that thermodynamics could reduce the solution space because the Second Law requires that the product of the reaction rate and the Gibbs energy of reaction is negative for each and every enzyme reaction.

Estimating the Gibbs energy of reaction for all enzymatic transformations unfortunately introduces a host of new unknowns whose values have to be assumed. The authors of Chapter 22 have tested the reliability of such analysis using glycolysis as a test case, where most of these variables are 
known. The result of the analysis depends much on the values of such variables. Therefore, much more research is required before thermodynamics can be reliably applied to cellular metabolism.

\section{Conclusions}

The large body of knowledge on biothermodynamics available in the literature could be harnessed by biochemical engineers to facilitate bioprocess development and potentially reduce the requirement for experimental work. The area of biomolecular thermodynamics (Figure 1) is especially well developed; its use ought to be encouraged as much as possible. Although scarcely applied in practice, the subarea of thermodynamics of live cells based on black-box models (Figure 1) is also expected to enhance bioprocess research and development, particularly for predicting culture performances, for understanding the driving forces for cellular growth, and for developing, monitoring, and controlling cellular cultures. Finally, there is no question that thermodynamic analysis of cellular metabolism (Figure 1) is a promising tool for systems biology and for many other applications. It also represents the bridge that must be crossed to finally describe the thermodynamics of live cells directly in molecular terms.

\section{Bibliography}

[1] McQuarrie, D. A. and Simon, J. D., Molecular Thermodynamics, University Science Books, Sausalito, CA, 1999.

[2] von Stockar, U. and van der Wielen, L. A. M., Back to basics: Thermodynamics in biochemical engineering, Adv. Biochem. Eng. Biotechnol., 80 (2003), 1-17.

[3] von Stockar, U. (ed.), Biothermodynamics for Biochemical Engineering, Presses polytechniques et universitaires romandes, Lausanne, 2013.

[4] von Stockar, U., Biothermodynamics of live cells: A tool for biotechnology and biochemical engineering, J. Non-Equilib. Thermodyn., 35 (2010), 415475 .

[5] Prausnitz, J. M., Some new frontiers in chemical engineering thermodynamics, Fluid Phase Equilib., 104 (1995), 1-20. 
[6] Reschke, M. and Schügerl, K., Reactive extraction of Penicillin II: Distribution coefficients and degrees of extraction, Chem. Eng. J., 28 (1984), B11B20.

[7] Dey, S. S. and Prausnitz J. M., Opportunities for chemical engineering thermodynamics for biotechnology: Some examples, Ind. Chem. Res., 50 (2011), 3-15.

[8] Orella, C. J. and Kirwan, D. J., Correlation of amino acid solubilities in aqueous aliphatic alcohol solutions, Ind. Eng. Chem. Res., 30(5) (1991), 10401045.

[9] Coen, C., Chiew, Y. C., Blanch, H. W. and Prausnitz, J. M., Salting out of aqueous proteins: Phase equilibria and intermolecular potentials, AIChE J., 41(4) (1996), 996-1004.

[10] Gude, M. T., van der Wielen, L. A. M. and Luyben, K. C. A. M., Phase behavior of $\alpha$-amino acids in multicomponent aqueous alkanol solutions, Fluid Phase Equilib., 116 (1996), 110-117.

[11] Gude, M. T., Meuwisen, H. H. J., van der Wielen, L. A. M. and Luyben, K. C. A. M., Partition coefficients and solubilities of $\alpha$-amino acids in aqueous 1-butanol solutions, Ind. Chem. Eng. Res., 35 (1996), 4700-4712.

[12] Tramper, J., Vermüe, M. H., Beeftink, H. H. and von Stockar, U. (eds.), Biocatalysis in Non-Conventional Media. Progress in Biotechnology 8, Proceedings of an International Symposium. Noordwijkerhout 1992, Elsevier, Amsterdam, 1992.

[13] Liu, J. S., Marison, I. W. and von Stockar, U., Microbial growth by a net heat up-take: A calorimetric and thermodynamic study on acetotrophic methanogenesis, Biotechnol. Bioeng., 75 (2001), 170-180.

[14] Heijnen, J. J., van Loosdrecht, M. C. M. and Tijhuis, L., A black-box mathematical model to calculate auto- and heterotrophic biomass yield based on Gibbs energy dissipation, Biotechnol. Bioeng., 40 (1992), 1139-1154.

[15] von Stockar, U., Maskow, T., Liu, J. S., Marison, I. W. and Patino, R., Thermodynamics of microbial growth and metabolism: An analysis of the current situation, J. Biotechnol., 121 (2006), 517-533.

[16] Tijhuis, L., van Loosdrecht, M. and Heijnen, J. J., A thermodynamically based correlation for maintenance Gibbs energy requirements in aerobic and anaerobic chemotrophic growth, Biotechnol. Bioeng., 42 (1993), 509-519. 
Received January 10, 2013; accepted April 28, 2013.

\section{Author information}

Urs von Stockar, Institut des Sciences et de l'Ingénierie Chimique, Swiss Federal Institute of Technology, CH-1015 Lausanne, Switzerland; and Dublin City University, Dublin, Ireland.

E-mail: urs.vonstockar@epfl.ch 